\title{
Slovenia: Focus on Energy Efficiency, Community Energy Projects and Energy Poverty
}

\author{
Lidija Živéič and Tomislav Tkalec
}

\begin{abstract}
Slovenia has a small energy sector, where oil (45\%) represents the main energy source. Electricity generation is equally divided between hydropower, nuclear energy and coal. Trends in energy policy go in the direction of maintaining status quo. A significant percentage of households live in energy poverty due to combination of low energy efficiency of buildings, high ownership rates, and low incomes. The Sustainable Energy Consumption Initiatives (SECIs) reviewed in this chapter are generally ahead of the trends in national energy policies. The progressive nature of many SECIs is evident in the field of energy efficiency and diversity of effective approaches, in particular in the cases of community renewable energy initiatives and the problem of energy poverty. Policymakers still do not fully appreciate the relevance of these areas for a sustainable transition. Especially in areas of community energy and energy
\end{abstract}

\section{L. Živčič $(\bowtie) \cdot$ T. Tkalec}

Focus Association for Sustainable Development, Ljubljana, Slovenia

e-mail: lidija@focus.si

T. Tkalec

e-mail: tomi@focus.si

(C) The Author(s) 2019

F. Fahy et al. (eds.), Energy Demand Challenges in Europe, https://doi.org/10.1007/978-3-030-20339-9_9 
poverty, SECIs provide recommendations to decision-makers on how to proceed in dealing with these issues.

Keywords Slovenia - Energy poverty - Community energy projects • Energy policy • Sustainable energy initiatives

\section{INTRODUCTION}

Slovenia has a small energy sector, with final energy consumption in 2017 of 4.92 Mtoe $(57,242 \mathrm{GWh})$. Oil $(45 \%)$ is the main energy source, followed by electricity $(24 \%)$, renewables $(14 \%)$, natural gas $(12 \%)$, heat (4\%) and solid fuels (1\%) (SURS 2018). Electricity generation can be divided into three parts-hydropower (38\%), nuclear power $(37 \%)$ and thermal power $(22 \%)$ - that vary slightly from year to year because of weather conditions and the amount of rainfall, which influences generation in hydropower plants. The biggest share of thermal power comes from one coal-fired plant (lignite). Renewables contribute only a small share of electricity generation, with solar accounting for less than $2 \%$, and even less wind energy (0.02\%) (ARSO 2015). Slovenian energy independence in 2017 was $52 \%$.

Even though the EU is one of the most developed areas in the world, between 50 and 125 million EU citizens are estimated to be energy poor. The situation is most severe in the Eastern Europe Member States, including Slovenia. In the majority of the new Member States, up to $30 \%$, or even more, of households are struggling with energy poverty. Following a brief overview of household energy use and energy policy in Slovenia, this chapter presents details of a sustainable energy initiative that aimed to alleviate energy poverty in Slovenia and neighbouring countries.

\section{Socio-Material Dynamics of Household Energy Use in Slovenia}

Future growth in electricity consumption must be considered given the expansion of air conditioning and electric vehicles. Energy efficiency measures, in particular insulation of multi-apartment buildings and family houses, serve as a counterbalance to these increases. However, improvements in thermal insulation are usually concentrated in the 
better-off sectors of the population, while the less well-off are less able to invest in improving energy efficiency of their dwellings. A significant percentage of households live in energy poverty, primarily because of low energy efficiency of buildings in combination with high ownership rates (more than $95 \%$ of people live in their own flat or house) and low incomes. Due to rising prices of heating oil in the last 10 years, there is a tendency to replace oil for heating with cheaper alternatives. While some households use heat pumps and gas, an increasing number choose biomass, as wood is the cheapest option. However, the large percentage of heating with biomass leads to an increasing problem with air pollution.

\section{Energy Policy in Slovenia}

The government has worked on a new national energy concept since the autumn of 2014, but the programme has not yet been adopted. The current version focuses on keeping the status quo and preparing for changes in the longer term. Slovenia's vision for the energy sector is gradually to transition to low-carbon energy sources by focusing on efficient energy consumption, use of renewable energy sources (RES) and the development of active electricity-distribution networks. This strategy will likely envisage a strong reliance on nuclear energy and further development of hydroelectric power (Export.gov 2017).

While the gas and oil markets are somewhat privatised, electricity production is still in state hands. The major electricity producers in Slovenia, Holding Slovenske Elektrarne (HSE) and Gen Energija (GEN), are fully owned by the state of Slovenia. These two companies formed a single unit until 2001. In recent years, the government has considered reverting to a single company through the merger of HSE and GEN, as HSE did not have the necessary financing for the construction of a new coal-fired generator at the Šoštanj Thermal Power Plant (TEŠ 6). Nonetheless, construction on the TEŠ 6 project continued despite concerns about its cost, commercial feasibility, environmental impact and the perceived lack of transparency surrounding the project. Despite these concerns, the government of Slovenia provided the necessary loan guarantees to finish the project, and TEŠ 6 went on-line in 2015 (Export.gov 2017). There is still no definite answer about the timing of closure of the coal power plant TEŠS, as its life expectancy until 2054 is not likely to be met because of economic and environmental reasons. 
RES are still not a government priority, and bigger investments (apart from hydropower) are not planned until after the year 2030. Increased hydroelectric power generation is one of the strategic objectives of the government's energy policy. Further upgrading of existing stations on the Sava and Drava rivers is planned, as well as the construction of several new plants on the Sava, and several other small hydroelectric power plants. Together with the new plants, these renovations should create an additional $470 \mathrm{MW}$ of hydroelectric capacity in the near future (Export. gov 2017).

GEN Energija has prepared a plan for a second nuclear production facility. However, the government's decision on the timing of any possible nuclear expansion will depend on energy needs, available financing and public sentiment about nuclear energy. GEN Energija currently owns half of the Krško Nuclear Power Plant, which is co-owned by Croatia's state company HEP (Export.gov 2017).

Energy efficiency and energy refurbishment of the building stock are perceived as priority measures, but are not fully visible in government financial schemes and policies. Energy communities are only slowly entering the discourse.

\section{Trends in National Household \\ Energy Campaigns in Slovenia}

National campaigns in Slovenia are run mainly through the national organisations Eco Fund and Energy Agency. Eco Fund has programmes and financial aids for energy efficiency (EE) and RES measures (e.g. energy refurbishment of buildings, replacement of old inefficient heating systems, energy advising, energy poverty alleviation programmes, co-financing investments in RES, subsidies for electric cars). Energy Agency is responsible for tenders for support schemes for RES projects.

The Ministry for Environment is also active in campaigns for cleaner air, targeting air pollution from wood burning. Other non-governmental stakeholders and actors, including utility companies, run campaigns on RES projects and 'prosumership' of RES electricity through a net metering scheme, which allows consumers who generate their own electricity to use that electricity at any time. Community groups run campaigns based on community (RES) projects, energy efficiency, energy poverty and sustainable mobility. Apart from being active in the promotion of EE 
and RES, community groups are also involved in campaigns against fossil fuels and nuclear power.

\section{Characteristics of National SECIs in Slovenia}

A review of recent Sustainable Energy Consumption Initiatives (SECIs) in Slovenia, according to their problem framing, reflects the dominance of traditional problem framings that prioritise changes in individuals' behaviour and changes in technology (Table 9.1). There are only a few initiatives that understand the challenge of changing energy use as a more complex and collective concern and several initiatives that target changes in everyday life situations.

Table 9.1 Number of national SECIs in Slovenia according to their problem framing

Changes in complex interactions

‥4 Changes in everyday life situations

(3) Changes in individuals' behaviour

In Slovenia, SECIs are generally ahead of the trends in national energy policies. The progressive nature of many SECIs is already evident in the field of energy efficiency and diversity of effective approaches, in particular in the cases of RES initiatives, community energy projects and the problem of energy poverty. Policy-makers still do not fully appreciate the relevance of these areas for a sustainable transition. Especially in areas of community energy and energy poverty, SECIs provide examples to decision-makers on how to proceed in dealing with these issues. 
Often, non-governmental actors take the initiative in these areas and, on the basis of their acquired knowledge and experience, influence the policy-makers who, due to these SECIs, are beginning to deal with the topics concerned (namely energy poverty and community energy).

There is some attention paid in SECIs to the socio-material specifics of energy use. Energy efficiency is high on the agenda of several SECIs. Energy poverty is highlighted as one of the socio-material aspects and is reflected in ten of the identified SECIs. One visible characteristic of SECIs that target energy poverty is that many of them work with such households in a variety of manners, from working towards energy retrofits, to providing home audits, energy advising, awareness raising, understanding of energy and heating bills, participatory workshops on energy saving, providing financial support and other support measures.

The majority of identified SECIs focus on changes in individuals' behaviour (23), followed by changes in technology (11), while those that focus on changes in complex interactions are scarce (4). However, there are seven SECIs focusing on changes in everyday life situations. The majority of SECIs identified in Slovenia are run at a cross-national level (24), 15 are implemented at a national level, 5 at a regional level and 5 at a local level. The majority of the Slovenian cases are built around energy efficiency (combination of reduction and substitution) and substitution.

Governmental programmes are rather scarce, and many initiatives come from EU projects, energy agencies and initiatives by the environmental NGOs. Actions are mostly not targeted to specific sociodemographic groups, although there are quite a high number of initiatives targeting low-income households (10), which shows that energy poverty is recognised as an important issue.

\section{CAse Study: REACH (Reduce Energy Use and Change Habits)}

REACH (Reduce energy use and change habits) is an IEE-funded project (2014-2017) aimed at reducing energy consumption in low-income (energy poor) households. It was implemented in Croatia, Macedonia, Bulgaria and Slovenia. In Slovenia, the project was administered by FOCUS. In all countries, practical activities of the project-energy advising in households-were conducted on a regional level. In Slovenia, the project was run in the Pomurje and Zasavje regions. 
REACH built on the success of a previous IEE project, ACHIEVE. Project REACH had two overall objectives: (i) to empower energy-poor households to take actions to save energy and change their habits; and (ii) to establish energy poverty as an issue that demands tailor-made policies and measures at local, national and EU level. The specific aims of the project were:

- To compile data and analyse energy poverty situations in four countries in order to form definition(s) of energy poverty and policy recommendations.

- To engage and empower local actors to tackle energy poverty.

- To empower energy-poor households to reduce their energy and water use and to provide some of them with further support for tackling their problems.

- To engage decision-makers in tackling energy poverty as an issue that demands structural tailor-made solutions, to provide them with recommendations for addressing the problem and to create a platform for concerted formulation of structural solutions at the national and EU level.

\section{Framing the Energy Challenge}

Energy poverty in Slovenia is becoming an increasing problem as rising energy prices surpass the rise of incomes of the population. Thus, the expenditure on energy for households in the first income quintile has risen sharply in the recent couple of years, representing $17 \%$ of all available resources of individual households in 2010 (in 2000, this share was $13 \%)$. In the context of EU policies, the issue of energy poverty is becoming more and more visible, but there is no single definition of who is energy poor. Despite the lack of definition, energy poverty is being tackled by some policies: governmental analysis of energy poverty from 2010 highlights energy poverty as a rising issue, and the National Energy Action Plan 2020 and the Operative programme 2014-2020 list energy retrofit of energy-poor households as an objective. Hence, some measures for addressing energy poverty already exist in Slovenia: the national programme for visiting energy-poor households by advisers of the national energy efficiency advising network, support for energy retrofits of energy-poor households (100\% subsidy), and support for the 
replacement of heating systems in energy-poor households in areas that are particularly burdened with air pollution. However, further steps are necessary to address the problem fully.

\section{Methods for Intervention}

The first step of the project was to map the local and national situation in the field of energy poverty. National analyses of the energy poverty situation were conducted in order to (i) gain insight into the situation; (ii) provide a basis for fine-tuning the action; and (iii) provide a basis for shaping policy recommendations. The other main activity was the transfer of knowledge for energy advising to partners, teachers and students of vocational schools. The transfer was made through training for partners, who subsequently transferred the know-how to their local vocational schools through ten training events for teachers and students. After equipping students-trained as energy advisors-with the tools and techniques for visiting households, household visits commenced. Households were approached in cooperation with Centres for Social Work (an information flyer was prepared and the Centres collected households' applications for visits).

During the first visit, the advisors made an energy audit of the household and studied its habits. Based on these inputs, tailored advice was given to each household in order to empower them to reduce energy and water use. Apart from advice, the households also received free energy- and water-saving devices that helped them to make further savings.

\section{Types of Outcomes}

Results for the overall project (for four countries combined) show that over 200 students and volunteers from vocational schools and faculties were trained to perform energy audits in energy-poor households. They helped partners to implement 1564 household visits, whereby basic energy efficiency measures were put in place and over 6650 free energyand water-saving devices were installed. The investment of about $€ 30$ worth of free devices resulted in annual savings of over $€ 65$ in the visited households, or over $€ 560$ saved during the lifetime of devices. In total, $€ 48,200$ was invested in energy-saving devices that could save over $€ 840,000$ during the lifetime of the devices. 
Overall, the initiative was considered successful. Apart from the practical quantitative level of reducing energy consumption in households, it was successful also on a structural level through informing policy issues. Participants found the visits very helpful, especially in terms of understanding their energy and water use better, but they also showed high appreciation for the free energy- and water-saving devices.

\section{Conclusion}

Slovenia has a small energy sector, where oil with its $45 \%$ share represents the main energy source (mainly for transport). Electricity generation can be divided in three similarly sized parts: hydropower, nuclear energy and coal. Trends in energy policy, as prepared in the new proposal for the national energy concept, go in the direction of keeping the status quo regarding current energy sources, while also trying to follow EU directives and fulfil EU targets for renewable energy, energy efficiency and GHG emissions.

The emphasised SECI provides an example of initiative that is focusing on energy poverty and includes activities on practical and structural levels. The cross-national project's aim was to reduce energy consumption in low-income households, which it achieved through knowledge exchange and the provision of energy advice. Results show over $€ 65$ of savings per household per year on average, which is significant for many Slovenian households. It also included policy aspects, as advocacy activities were part of the project. Results from the practical part of the project were used for advocacy work and, in that way, decision-makers were presented with a 'ready-to-use' scheme. Engaging decision-makers on the national level and their activation on the topic of energy poverty, and subsequent preparation of a nationwide programme for energy poverty alleviation was one of the main successes of the REACH project.

\section{REFERENCES}

ARSO. (2015). Kazalci okolja: [EN30] Proizvodnja in raba električne energije (kazalec združuje kazalca EN12 in EN17). Available at http://kazalci.arso. gov.si/sl/content/proizvodnja-raba-elektricne-energije-kazalec-zdruzuje-kazalca-en12-enl7?tid=4. Accessed 6 February 2019.

Export.gov (2017). Slovenia-Electrical power systems and energy. Available at https://www.export.gov/article?id=Slovenia-Electrical-Power-Systems. Accessed 6 February 2019. 
SURS. (2018). Količina energije, namenjene končni rabi, je v letu 2017 znašala 206.000 TJ. Available at https://www.stat.si/StatWeb/News/Index/7722. Accessed 6 February 2019.

Open Access This chapter is licensed under the terms of the Creative Commons Attribution 4.0 International License (http://creativecommons.org/licenses/ by $/ 4.0 /$ ), which permits use, sharing, adaptation, distribution and reproduction in any medium or format, as long as you give appropriate credit to the original author(s) and the source, provide a link to the Creative Commons license and indicate if changes were made.

The images or other third party material in this chapter are included in the chapter's Creative Commons license, unless indicated otherwise in a credit line to the material. If material is not included in the chapter's Creative Commons license and your intended use is not permitted by statutory regulation or exceeds the permitted use, you will need to obtain permission directly from the copyright holder.

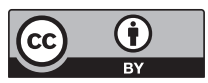

